\title{
Post traumatic stress disorder among adults in the aftermath of 2011 Van-Ercis earth- quake in Turkey
}

\author{
2011 yılı Van-Erciş depremi sonrası yetişkinlerde travma sonrası stres \\ bozukluğu \\ Mehmet Hamid Boztas ${ }^{1}$, Ahmet Tamer Aker², Kerim Munir3, Feyza Çelik ${ }^{4}$, Adem Aydin 5 , Umut Karasu6, \\ Elif Aktan Mutlu 7 \\ ${ }_{1}^{1}$ Assoc. Prof., Abant İzzet Baysal University, Department of Psychiatry, Bolu, Turkey https://orcid.org/0000-0001-6541-0666 \\ 2Prof., Bilgi University, Department of Psychiatry, Istanbul, Turkey https://orcid.org/0000-0001-5579-3552 \\ 3M.D., Harvard University, Children's Hospital, Department of Child and Adolescent Psychiatry, USA https://orcid.org/0000-0002-2404-1806 \\ ${ }^{4}$ M.D., Dumlupınar University, Research and Training Hospital, Kutahya, Turkey https://orcid.org/0000-0003-2128-3014 \\ ${ }^{5}$ Assoc. Prof., Necmettin Erbakan University, Department of Psychiatry, Konya, Turkey https://orcid.org/0000-0003-3687-6832 \\ 6 M.D., Community Mental Health Center, Balıkesir, Turkey \\ $7_{\text {M.D., Bursa State Hospita, Bursa, Turkey https://orcid.org/0000-0002-0889-1421 }}$
}

\section{SUMMARY}

Objective: The aims of the study were to: (i) screen for PTSD among subjects older than 15 years old living in the Ercis-Van region nine months after the earthquake; and (ii) examine the socio-demographic, clinical and trauma-related factors of PTSD diagnosis. Method: At the time of the earthquakes, the population of Ercis-Van region was $1,050,000$. We selected 1498 participants in these areas: 996 from Van and 502 from Ercis, centers using a stratified sampling frame (Kish design). Demographic information, trauma related experiences and past psychiatric history was obtained via sociodemographic survey. The PTSD module of the Composite International Diagnostic Interview (CIDI), along with depression, dysthymia, social anxiety disorder, obsessive compulsive disorder, generalized anxiety disorder structured interview modules were used to directly elicit clinical information. Results: We found that PTSD was prevalent $35.5 \%$ among Van earthquake survivors. Analysis of binary Logistic regression showed risk factors, which included some trauma related losses, pre and post traumatic experiences. These risk factors are being female, having depression, loosing any family members or relatives, being unemployed, having serious familial conflicts, severe financial loss, and temporary relocation. Discussion: Our results indicate that in addition to being women, having depression, trauma related losses, like previous traumatic experiences, some pre and post traumatic risk factors are important for development of PTSD. Therefore, after the traumatic event, community based interventions should be structured based on these pre and post disaster risk factors.

Key Words: Traumatic Stress, Community Psychiatry, Mental Health

(Turkish J Clinical Psychiatry 2019;22:380-388)

DOI: $10.5505 / k p d .2019 .62534$

\section{ÖZET}

Amaç: Bu çalışmanın amaçları; (i) Van Depreminden dokuz ay sonra Van-Erciş bölgesinde yaşayan 15 yaş üstüı bireylerde Travma Sonrası Stres Bozukluğunu taramak ve (ii) Travma Sonrası Stres Bozukluğu tanısını yordayabilecek sosyodemografik, klinik ve travmayla ilişkili etmenleri gözden geçirmektir. Yöntem: Deprem sırasında Van ve Erciş bölgelerinde 1,050,000 kişi yaşamakta idi. Araştırmaya tabakalandırılmış örneklemle (Kish Metodu) Van'dan 996, Erciş'ten 502 kişi alınmıştır. Sosyodemografik veri formu aracılığıla demografik bilgiler, travmayla ilişkili deneyimler ve geçmiş psikiyatrik öykü elde edilmiştir. Klinik bilgiler için Uluslararası Bileşik Tanı Görüşmesi/ Composite International Diagnostic Interview (CIDI)'nin TSSB, depresyon, distimi, sosyal anksiyete bozukluğu, obsesif kompulsif bozukluk ve yaygın anksiyete bozukluğu modülleri kullanılmıştır. Bulgular: Van depremi sonrasında deprem mağdurlarında TSSB oranını \%35.5 olarak bulduk. Binary Lojistik regresyon analizi travmayla ilişkili , travma öncesi ve sonrası kimi etmenleri TSSB için risk faktörü olarak göstermiştir. Bu faktörler kadın olmak, depresyonda olmak, aile üyelerini veya bir yakınını kaybetmek, ciddi sağlık ve barınma sorunları yaşamak, işsiz,olmak, aile içi ciddi çatışmaların varlığı, ciddi finansal zorluk, geçici yer değiştirmedir. Sonuç: Araştırmamızın sonuçları depresyon, kadın cinsiyet, travmayla ilişkili kayıplar yaşamaya ek olarak geçmiş travmatik deneyimler gibi travma öncesi ve sonrası kişide oluşan risk faktörlerinin TSSB gelişimde önemli olduğunu göstermiştir. Bu nedenle travma sonrası topluma dayalı çalışmalar afet öncesi ve sonrası risk faktörlerine dayandırılarak yapılandırılmalıdır.

Anahtar Sözcükler: Travma Sonrası Stres Bozukluğu, Toplum Psikiyatrisi, Ruhsal Sağlık 


\section{INTRODUCTION}

A magnitude of 7.2 (on the Richter scale) earthquake struck Van-Ercis region in Eastern Turkey on October 23, 2011, followed by a second earthquake, magnitude 5.6 (on the Richter scale), on November 9, 2011(1). A total of 644 person lost their lives, 252 were pulled alive from the debris and a total of 1,966 persons were injured. The disaster was particularly devastating because it struck a region that is beset by gender, ethnic, language and socioeconomic disparities. Education level is low, unemployment and poverty are very high in the Van-Ercis region. According to TIS, in 2008, Gross value added is $3419 \$$ in Mus, Hakkari, Bitlis, Van region. Mean Gross value added is $9384 \$$ in the country. Van had $17.2 \%$ unemployment rate in 2010, which is third highest rate in all Turkey. Illiterate rate of women is nearly twofold higher in Van compare to mean illiterate rate of women in Turkey (18.6\%/9.5\%) (2). Most of the women and elderly speak only in their native Kurdish language (3).

Although post-traumatic stress disorder (PTSD) is the most frequently studied mental health condition following disasters (4), reports of its prevalence vary and range from $2 \%$ to $87 \%$ $(5,6,7,8,9,10,11)$. Such variations are related to factors involving differences in the magnitude of the exposure, quality of buildings, timing of the event, as well as assessment of PTSD outcomes with respect to the diagnostic instruments used, proximity of the assessments to the time passed from the event and social and cultural conditions salient for the population. Studies show that disaster exposure variables, such as death and/or injury of family members (12), severe residential damage have been associated with occurrence of PTSD. Several studies have shown that PTSD is related with severe damage of housing $(13,14,15)$ and death of family members $(13,16)$.

It is of interest that the prevalence rates for PTSD from Turkey, as well as Armenia and Iran, have consistently been higher than other countries. For instance, prevalence of PTSD found 39\% to 63\% among survivors of the Marmara earthquake in $1999(17,18)$. The reported prevalence rates for
Yerevan earthquake in Armenia, and the Bam earthquake in Iran (12) were nearly twice as higher than figures reported from China and Taiwan (4, $5,19)$.

Factors such as poverty, lower levels of perceived support, gender, physical illness and other factors affect rate of PTSD and other psychiatric disorders after disasters $(12,17,20,21,22)$. Post-disaster period affects mental status of the victims and longer periods of recovery increases PTSD symptoms via second traumatization process $(12,23)$. Parental response, migration, distance between home and earthquake epicenter, prior personal or family history of a mental health disorder, loss of family members or close friends are other important risk factors $(17,18,24,25)$.

There have been inconsistent reports on risk factors for PTSD after an earthquake. Six months after the earthquake, Kadak and associates found that prevalence of severe PTSD was almost 40 percent among child and adolescents in high school students. (26) Another study also found high prevalence of PTSD symptoms in a population based study using clinical scales in same region (27). Some reports stated that women are under increased risk of having PTSD and depression (20, $28,29,30)$. There are no PTSD studies using structured interview that evaluate pre and post disaster risk factors and its relations with population that lived in disaster area after Van earthquake.

The aim of the present study is to investigate prevalence of PTSD and associated risk factors in a large community sample in eastern Turkey after the Van earthquake. The aims of the study were to: (i) screen for PTSD with among subjects older than 15 years living in the Ercis-Van region nine months after the earthquake; and (ii) examine the sociodemographic, clinical and trauma-related predictors of PTSD diagnosis.

\section{METHOD}

Participants and study background

Study Population Characteristics 
At the time of the earthquakes the population of Ercis-Van region was $1,050,000$. The overall population demographics with respect to ethnicity and primary language were not known as data is not collected by the National Institute of Statistics. The study sample was selected from the population of the two most highly affected centers in Ercis and Van, with populations of 500,000 residents in each town center, respectively. These included all 28 districts and 11 temporary shelters in the Van center and in the Ercis center as the most severely affected areas. We selected 1498 participants in these areas: 996 from Van and 502 from Ercis, centers using a stratified sampling frame (Kish design). Households were selected randomly in the district. All participants were 15 years and older. Written informed consent was obtained from all participants and the study was approved by the research ethics committee based at the Kocaeli University.

\section{Measures}

The demographic information obtained consisted of each subject's age, gender, level of education and employment status. Trauma-related experiences assessed included the impact of the earthquake, e.g., economic losses, temporary relocation, loss of family member(s), initial difficulty in finding shelter immediately following the earthquake. The survey also inquired about psychiatric history and prior traumatic experience (e.g, witnessing death, suicide, fire, blast). The PTSD module of the Composite International Diagnostic Interview (CIDI), along with depression, dysthymia, social anxiety disorder, obsessive compulsive disorder, generalized anxiety disorder structured interview modules were used to directly elicit clinical information. This study used part of Van earthquake effect on mental health data sets. Another research paper about all psychiatric diagnosis has been planned to use in this data set.

\section{Procedure}

The survey teams included local staff of the provincial Ministry of Health in Ercis and Van districts comprised of social workers, psychologist and graduate students in psychology. The research team underwent a 3-day training workshop program con- ducted by two senior PhD level psychology staff at the Kocaeli University Psychological Trauma and Disaster Studies Unit. Overall, of the 1710 persons contacted, 212 refused to participate with a response rate of $87.7 \%$. All interviews were carried out in a private place for privacy. Two trained experienced mental health workers gave supervision on a day-to-day basis. Research teams consisted of bilingual (Turkish-Kurdish) individuals, who were familiar with local cultural rules and customs. All data obtaining process took nearly three months.

We assessed the PTSD diagnosis if the participant had fear or desperation, 2 or more arousal symptoms, 3 or more avoidance symptoms, 1 or more reexperiencing symptoms and if the duration of the symptoms was longer than one month.

\section{Data Analysis}

Descriptive analyses were performed for demographic variables, trauma-related indicators, and PTSD symptoms, using $X^{2}$ and t-test to evaluate differences between the two groups (PTSD and others). SPSS 22.0 software was used to perform the statistical analysis. Bivariate logistic regression analysis was used to assess risk factors for presence of PTSD diagnosis. Odds ratios (OR) stated and in this analysis all statistically significant $p$-values reported were at $<0.05$.

\section{RESULTS}

The demographic characteristics, clinical and trauma-related features of the PTSD group and the non-PTSD group are presented in Table 1 . We try to describe PTSD symptoms in Van province after the earthquakes in Table 2.

More than $88 \%$ of PTSD symptoms were longer than one month. We examined PTSD symptoms according to DSM IV, frequency of each symptom is displayed in Table 2. The PTSD prevalence was $35.5 \%$. Sociodemographic features, event-related features and other factors were evaluated in this study for PTSD diagnosis. Gender, depression, serious health problem, shelter problem, physical disability, unemployment, serious financal prob- 
Boztas MH, Aker AT, Munir K, Celik F, Aydin A, Karasu U, Aktan Mutlu E.

\begin{tabular}{|c|c|c|c|c|c|c|c|c|c|c|c|}
\hline \multirow[b]{2}{*}{ Variables } & \multicolumn{4}{|l|}{ PTSD } & \multicolumn{4}{|c|}{ Non PTSD } & \multicolumn{3}{|c|}{ Comparison } \\
\hline & M & SD & $\mathrm{N}$ & $\%$ & M & $\mathrm{SD}$ & $\mathrm{N}$ & $\%$ & $? 2 / \mathrm{t}$ & df & $\mathrm{p}$ \\
\hline Age & 35.99 & 14,10 & 532 & 35,50 & 34,93 & 12,31 & 966 & 64,50 & 1,44 & 1496 & 0,15 \\
\hline \multicolumn{12}{|l|}{ Gender } \\
\hline Female & & & 392 & 40,0 & & & 588 & 60.0 & 24.903 & 1 & $0.001 *$ \\
\hline Male & & & 140 & 27,0 & & & 378 & 73,0 & & & \\
\hline \multicolumn{12}{|l|}{ Education } \\
\hline At least primary school & & & 324 & 60.9 & & & 567 & 58.8 & 3.955 & 2 & 0.138 \\
\hline $\begin{array}{l}\text { Middle school and high } \\
\text { school }\end{array}$ & & & 147 & 27.6 & & & 251 & 26.0 & & & \\
\hline College & & & 61 & 11.5 & & & 146 & 15.2 & & & \\
\hline \multicolumn{12}{|l|}{ Langauge } \\
\hline Turkish & & & 256 & 37,3 & & & 430 & 62,7 & 18.09 & 2 & $0.001 *$ \\
\hline Kurdish & & & 124 & 27,8 & & & 322 & 72,2 & & & \\
\hline Both & & & 151 & 41,4 & & & 214 & 58,6 & & & \\
\hline \multicolumn{12}{|l|}{ Unemployment } \\
\hline Yes & & & 267 & 40,3 & & & 396 & 59,7 & 12.304 & 1 & $0.001 *$ \\
\hline No & & & 251 & 31,45 & & & 547 & 68,55 & & & \\
\hline \multicolumn{12}{|l|}{$\begin{array}{l}\text { Psychiatric disorder } \\
\text { history in family }\end{array}$} \\
\hline Yes & & & 56 & 50,00 & & & 56 & 50,00 & 10,463 & 1 & $0,001 *$ \\
\hline No & & & 440 & 34,70 & & & 828 & 65,30 & & & \\
\hline
\end{tabular}

lem, conflict in family, new member in shelter, spouse with mental health problem, witnessing fire and explosion, witnessing suicide, history of temporary relocation, loss in family, history of psychiatric disorder in family were correlated with PTSD diagnosis (Table 3 ).

Binary logistic regression was conducted to assess whether the fifteen predictor variables, gender, depression, serious health problems, shelter problem, physical disability, unemployment, serious financal problem, conflict in family, new member in shelter, spouse with mental health problem, witnessing fire and explosion, witnessing suicide, history of temporary relocation, loss in family, history of psychiatric disorder in family significantly predicted whether or not a participants giving PTSD diagnosis $(\mathrm{R} 2=0.168$ and $\mathrm{p}<0.05)$. When all fifteen predictor variables are considered together, they significantly predict whether or not having PTSD diagnosis, $X^{2}=157.132 \mathrm{df}=15, \mathrm{~N}=1498, \mathrm{p}<$ .001 . Table 4 presents the odds ratios, which suggest that the odds of estimating correctly who are having depression, being women, serious financal loss, loss of close family member, serious intra familyal conflict, temporary relocation, predicted having PTSD.

\section{DISCUSSION}

This study is one of the few studies which assessed the related factors of PTSD based on structured interview after a devastating earthquake in (VanErciş) in Turkey. This study has the earliest assessment time to date among those studies. Van is a city located in the east region of Turkey where unemployment is more common, and the population is less educated, also they have experienced different types of traumatic events (recurrent earthquakes, armed conflict etc.) in the past years $(2,3)$. In addition to the previous serious life events, related with the earthquake, population confronted different types of stressors, such as unexpected death of reatives, relocation after the earthquake, and economical loss $(21,22,29)$. Our study shows that the rate of PTSD was $35.5 \%$ approximately nine months after the 2011 Van earthquake. This was compatible with the previous studies conducted in the same region, which reported a PTSD rate of $40 \%$ among adolescents in high schools and adult populations $(26,27)$. Another study conducted in the same region shows a higher rate of PTSD symptoms and hopelessness among community based samples (27). They only assessed earthquake related trauma but did not assess other type of previous trauma history in their study. Our study has tried to analyze pre and posttraumatic events in community based samples. One other study assessed relocation effect among Van earthquake survivors and they found relocation increased PTSD occurrence similar to our results (29). PTSD rates reported in these studies after the 2011 Van earthquake are higher than having any kind of mental disorder rate (17.2\%) in Turkish Mental Health Profile (31) and similar to other earthquake studies in Turkey 
Table 2 PTSD symptoms on CIDI

\begin{tabular}{lll}
\hline PTSD ITEMS & $\mathrm{N}$ & $\%$ \\
\hline B. Re-experience & & \\
\hline B1. Intrusive recollections of the earthquake & 1084 & 80.7 \\
\hline B2. Repeating nightmares of the earthquake & 846 & 63.3 \\
\hline B3. Acting as if earthquake were recurring & 995 & 74.7 \\
\hline B4. Feeling worse when reminded of earthquake & 1042 & 78.5 \\
\hline B5. Reactivity to earthquake reminders & 706 & 52.9 \\
\hline 1 or more re-experience symptoms (a score of 6 or more) & 1138 & 76 \\
\hline C. Avoidance and numbing & & \\
\hline C1. Efforts to avoid thoughts or feelings associated with & 664 & 51.8 \\
\hline the earthquake & & \\
\hline C2. Efforts to avoid activities that arouse recollections of & 557 & 43.8 \\
\hline the earthquake & & \\
\hline C3. Shows amnesia of the earthquake & 463 & 36.2 \\
\hline C4. Diminished interest participation in activities & 473 & 37.4 \\
\hline C5. Detachment or estrangement from others & 470 & 36.4 \\
\hline C6. Restricted range of affects & 413 & 32.1 \\
\hline C7. Sense of foreshortened future & 541 & 42.5 \\
\hline 3 or more avoidance symptoms (a score of 15 or more) & 790 & 52.7 \\
\hline D. Arousal & & \\
\hline D1. Difficulty falling or staying asleep & 723 & 55 \\
\hline D2. Irritability or anger & 693 & 53.4 \\
\hline D3. Difficulty concentrating & 657 & 51.1 \\
\hline D4. Hypervigilance & 928 & 71.7 \\
\hline D5. Exaggerated startle response & 783 & 61.9 \\
\hline 2 or more arousal symptoms (a score of 10 or more) & 1028 & 61.7 \\
\hline (6) & & \\
\hline
\end{tabular}

$(6,7,8,9,10,11,17,18) \quad$ These results suggest that PTSD is prevalent among Van earthquake survivors.

Risk factors for developing PTSD were having depression, being women, serious financial loss, losing of close family member, serious intra familial conflict, history of relocation. That might be related to more prominent expression of fear and emotions in females compared to males $(20,27,31)$. Expression of feeling and fear are restricted in many cultures especially for men. This pattern may even be more prominent in Eastern Anatolia when compared with more industrialized and better educated Western parts of Turkey. Gender difference cannot be explained by culture alone, same is found in the west of Turkey and in other countries as well. There are some gender- based features that may affect mental health after the earthquake. Firstly, after the disaster, especially in earlier time period, women were more affected then man in chaotic conditions as seen in Table 1. Secondly, some cultural factors may prevent men to express fear (15, 20). Women's increased tendency to mental disorder might be related to biological differences, lower socio-economic status in the society and different attribution styles (20). As one may see TIS report, women in Van have less education and high poverty level that affect on high PTSD rate (2). Also depression and anxiety disorder level in vomen population higher than men population. Many studies show that women are prone to have fear based disorders such as PTSD (32). Sensitivity to stressfull and traumatic life experiences, emotional reactivity, hormonal differences, higher activation in limbic and attention-related brain structures may be responsible for these differences (32).

Some studies reported that older people are more vulnerable to psychological distress after the trauma, possibly as they may have less resources to cope with negative effects of disasters (28). We didn't find any relation between PTSD and age. In Eastern Turkey, lack of resources, poverty and unemployment is very common and it is not specific to elderly people.

Loss of family members was associated with PTSD diagnosis (19). PTSD group is much more likely to lose a family member (parent, sibling or brother /sister). Degree of loss in the disaster and risk of developing PTSD has a dose response relation (33). Recent earthquakes research showed that intense fear and perceived life threat were two key risk factors for mental disorders, including PTSD 
Table 3. Correlations between PTSD, earthquake related problems and clinical factors

\begin{tabular}{|c|c|c|c|c|c|c|c|c|c|c|c|c|c|c|c|}
\hline & & PTSD & $\begin{array}{l}\text { New } \\
\text { member } \\
\text { in } \\
\text { shelter }\end{array}$ & $\begin{array}{l}\text { Spouse } \\
\text { with } \\
\text { psychiatri } \\
\text { c } \\
\text { disorder }\end{array}$ & $\begin{array}{l}\text { Witnessi } \\
\text { ng } \\
\text { suicide }\end{array}$ & $\begin{array}{l}\text { Tempo } \\
\text { rary } \\
\text { relocati } \\
\text { on }\end{array}$ & $\begin{array}{l}\text { Severe } \\
\text { health } \\
\text { problem }\end{array}$ & $\begin{array}{l}\text { Shelter } \\
\text { proble } \\
\text { m }\end{array}$ & $\begin{array}{l}\text { Disabil } \\
\text { ity }\end{array}$ & $\begin{array}{l}\text { Unemp } \\
\text { loymen } \\
\mathrm{t}\end{array}$ & $\begin{array}{l}\text { Severe } \\
\text { financi } \\
\text { al loss }\end{array}$ & $\begin{array}{l}\text { trafa } \\
\text { milial } \\
\text { conflict }\end{array}$ & $\begin{array}{l}\text { Loss in } \\
\text { family }\end{array}$ & Gender & $\begin{array}{l}\text { Depres } \\
\text { sion }\end{array}$ \\
\hline PTSD & $\mathrm{r}$ & 1 & & & & & & & & & & & & & \\
\hline $\begin{array}{l}\text { New member } \\
\text { in shelter }\end{array}$ & $\begin{array}{l}\mathrm{p} \\
\mathrm{r} \\
\mathrm{p}\end{array}$ & $\begin{array}{l}, 056^{*} \\
, 032\end{array}$ & 1 & & & & & & & & & & & & \\
\hline $\begin{array}{l}\text { Spouse with } \\
\text { psychiatrici } \\
\text { disorder }\end{array}$ & $\begin{array}{l}\mathrm{r} \\
\mathrm{p}\end{array}$ & $\begin{array}{l}, 060^{*} \\
, 021\end{array}$ & $\begin{array}{l}, 078^{* *} \\
, 003\end{array}$ & 1 & & & & & & & & & & & \\
\hline $\begin{array}{l}\text { Witnessing } \\
\text { suicide }\end{array}$ & $\begin{array}{l}\mathrm{r} \\
\mathrm{p}\end{array}$ & $\begin{array}{l}, 051^{*} \\
, 050\end{array}$ & $\begin{array}{l}, 084^{* *} \\
, 001\end{array}$ & $\begin{array}{l}, 165^{* *} \\
, 000\end{array}$ & 1 & & & & & & & & & & \\
\hline \multirow{2}{*}{$\begin{array}{l}\text { Temporary } \\
\text { relocation } \\
\text { Severe health } \\
\text { problem }\end{array}$} & $\begin{array}{l}\mathrm{r} \\
\mathrm{r} \\
\mathrm{p}\end{array}$ & , $163^{* * *}$ & , $079^{* * *}$ & ,077 & $\begin{array}{l}, 126^{* *} \\
, 000\end{array}$ & 1 & & & & & & & & & \\
\hline & $\mathrm{r}$ & $\begin{array}{l}, 112^{* * *} \\
.000\end{array}$ & $\begin{array}{l}-, 015 \\
563\end{array}$ & $\begin{array}{l}135^{* *} \\
000\end{array}$ &, $067^{*}$ & $\begin{array}{l}, 060^{*} \\
.023\end{array}$ & 1 & & & & & & & & \\
\hline \multirow{3}{*}{$\begin{array}{l}\text { Shelter } \\
\text { problem } \\
\text { Disability }\end{array}$} & $\begin{array}{l}\mathrm{p} \\
\mathrm{r}\end{array}$ &, $081^{* * *}$ & , &, $081^{* *}$ &,- 018 & -,001 &, $154^{* *}$ & 1 & & & & & & & \\
\hline & $\mathrm{p}$ & ,002 &, 108 & ,002 & ,486 & ,979 & ,000 & & & & & & & & \\
\hline & $\mathrm{r}$ &, $067^{*}$ & $\begin{array}{l}-, 001 \\
984\end{array}$ & $083^{* *}$ &, $069^{* *}$ &, 028 & $140^{* * *}$ &, $107^{* *}$ & 1 & & & & & & \\
\hline \multirow{5}{*}{$\begin{array}{l}\text { Unemploymen } \\
\mathrm{t} \\
\text { Severe } \\
\text { financial loss } \\
\text { Intra familial } \\
\text { conflict }\end{array}$} & $\begin{array}{l}\mathrm{p} \\
\mathrm{r}\end{array}$ & $\begin{array}{l}, 010 \\
, 092^{* *}\end{array}$ & $\begin{array}{l}984 \\
, 041\end{array}$ & $\begin{array}{l}, 001 \\
, 070^{* *}\end{array}$ & $\begin{array}{l}, 008 \\
, 069^{* *}\end{array}$ & $\begin{array}{l}, 288 \\
, 004\end{array}$ & $\begin{array}{l}, 000 \\
, 177^{* *}\end{array}$ & $\begin{array}{l}, 000 \\
, 211^{* *}\end{array}$ &, $061^{*}$ & 1 & & & & & \\
\hline & $\mathrm{p}$ & 000 &, 122 & , 007 & 008 & 886 & ,000 &, 000 &, 021 & & & & & & \\
\hline & $\mathrm{r}$ &, $150^{* * *}$ &, $116^{* *}$ &, $110^{* * *}$ &, $057^{*}$ &, $159^{* *}$ &, $162^{* * *}$ &, $313^{* *}$ & 031 &, $216^{* *}$ & 1 & & & & \\
\hline & $\mathrm{p}$ & ,000 &, 000 & ,000 & 027 & ,000 &, 000 &, 000 & 229 & ,000 & & & & & \\
\hline & $\mathrm{r}$ &, $142^{* *}$ & ,058 &, $196^{* * *}$ &, $073^{* *}$ &, $191^{* *}$ & $\begin{array}{l}129^{* * *} \\
000\end{array}$ & $086^{* * *}$ &, 011 &, $139^{* * *}$ &, $100^{* * *}$ & 1 & & & \\
\hline \multirow[t]{2}{*}{ Loss in family } & $\mathrm{r}$ & $146^{* * *}$ &, 005 &,- 014 & 001 & 007 &, $111^{* * *}$ & $076^{* *}$ & -,013 & ,060* & $148^{* * *}$ & ,019 & 1 & & \\
\hline & $\begin{array}{l}\mathrm{p} \\
\mathrm{r}\end{array}$ & $\begin{array}{l}, 000 \\
-129^{* *}\end{array}$ & $\begin{array}{l}, 861 \\
-, 004\end{array}$ & $\begin{array}{l}.593 \\
.016\end{array}$ & $\begin{array}{l}, 985 \\
-038\end{array}$ & $\begin{array}{l}, 797 \\
-077^{* *}\end{array}$ & $\begin{array}{l}, 000 \\
-, 052^{*}\end{array}$ & $\begin{array}{l}, 004 \\
-, 068^{* * *}\end{array}$ & $\begin{array}{l}, 622 \\
-, 010\end{array}$ & $\begin{array}{l}, 022 \\
-, 045\end{array}$ & $\begin{array}{l}, 000 \\
-, 020\end{array}$ & $\begin{array}{l}, 460 \\
-, 087^{* *}\end{array}$ &, $051^{*}$ & 1 & \\
\hline Gender & $\mathrm{p}$ & .000 & 888 & .539 & 139 & 003 & 045 & 009 & 709 & 083 & 448 & , & .048 & & \\
\hline \multirow[t]{2}{*}{ Depression } & $\mathrm{r}$ & $209^{* * *}$ & ,008 & ,086 & ,001 &, $078^{* * *}$ &, $075^{* * *}$ &, $071^{*}$ & ,031 & $145^{* * *}$ & $093^{* *}$ & $212^{* * *}$ &, $076^{* * *}$ &,$- 111^{* * *}$ & 1 \\
\hline & $\mathrm{p}$ & ,000 & ,782 & ,002 & ,980 & ,004 & ,007 & ,010 &, 271 & ,000 & ,001 & ,000 & ,006 & ,000 & \\
\hline
\end{tabular}

after the earthquake $(16,17,26,34,35,36,37,38,39)$. Witnessing some trauma-related event or loss of any family member may lead to more intense fear reactions and perceived life threat.

Using Turkish as the only language was significantly associated with PTSD in our study. It can be argued that, individuals speaking only Turkish were more likely to be related to government officers (i.e. they were not locals), therefore, they had lesser access to resources than local people in the region in terms of social support, which in turn lead to more prominent secondary stressors. This region is also a disparities zone, people generally work in unwanted conditions compare to other part of the country. Non-local people also may perceive disaster is another punishment $(2,3)$. Past psychiatric disorder, psychiatric disorder in the family, suicide history and psychiatric disorder of spouse were much more common in the PTSD group when compared with the non-PTSD group. Some of these factors were found to be associated with PTSD in previous studies $(34,36,38,39)$. Both PTSD and Major Depression share same risk factors. These are female gender, lower education, loss of friends and relatives. But depression is much more prevalent in individuals with loss of a family member and past psychiatric disorders $(9,17,36,38,39)$. Our results showed having MD was a probable predictor of PTSD. Other probable predictors were loss of any relatives, temporary relocation history, and female gender. There are several studies that focused on PTSD symptoms and associated features, yielding conflicting results. Possible reasons for inconsistencies may include sample size; assessment time and methods for PTSD, such as face-to-face structured interview or self-report surveys; and cultural and social differences. A study which reported $34.4 \%$ PTSD prevalence rate among tsunami survivors after two years of the event, used face to face structured clinical interview (37). Our results were similar to this study but we reported our results only 9 months after the earthquake. Former studies from previous Turkey earthquakes show different rates depending on their sample selection, assessment time, methods $(25,26,27,38,39)$. Because of sample selection and non-structured clinical assessment methods, these results may not be generalized the 
Table 4: Results of binary logistic regression on PTSD

\begin{tabular}{lllll}
\hline Variable & Beta & SE & Odds ratio & p \\
\hline Gender &,- 519 &, 127 &, 595 &, 000 \\
\hline Depression &, 215 &, 048 & 1,240 &, 000 \\
\hline Severe health problem &, 190 &, 132 & 1,209 &, 152 \\
\hline Shelter problem &, 058 &, 129 & 1,059 &, 656 \\
\hline Disability &, 496 &, 282 & 1,642 &, 078 \\
\hline Unemployment &, 105 &, 128 & 1,110 &, 414 \\
\hline Severe financial loss &, 311 &, 129 & 1,365 &, 016 \\
\hline ntra familial conflict &, 462 &, 219 & 1,587 &, 035 \\
\hline New member in shelter &, 337 &, 314 & 1,400 &, 283 \\
\hline Spouse with psychiatric disorder &,- 020 &, 409 &, 981 &, 962 \\
\hline Witnessing fire or explosion &, 358 &, 402 & 1,430 &, 374 \\
\hline Witnessing suicide &, 303 &, 813 & 1,354 &, 709 \\
\hline Temporary relocation &, 638 &, 151 & 1,893 &, 000 \\
\hline Loosing family member/ relative &, 657 &, 136 & 1,929 &, 000 \\
\hline Psychiatric disorder in family &, 353 &, 232 & 1,424 &, 130 \\
\hline$*$ p $<0.05$ & & & &
\end{tabular}

$\mathrm{p}<0.05$

population. Onder et al found a PTSD rate of 11.7 $\%$ three years after 1999 Marmara earthquake (16). PTSD rates decrease in time and Eastern and Western regions of Turkey have different social features. Our results were detected relatively closer time to the earthquake. PTSD rate is higher after the disaster and decrease as time passes. If we consider our irritability symptoms lower rate compare to other PTSD symptoms, time might affect fear response.

Resilience mechanisms are very important to prevent PTSD. These mechanisms are not only related with individuals but also affected by social and cultural characteristics. After the earthquake, the entire Turkey, as a country, tried to help the region. This process may be considered as social capital process $(9,40,41)$. Same mechanism was seen after the Marmara earthquake both in the national and international level (42). After the 1999 Marmara earthquake, many support mechanisms were established at both national and international level to get rid of the unhealthy consequences of the earthquake.

\section{Limitations}

There are some limitations in that study;

1)We assessed people who continued to live in the earthquake area (container cities and city). So, we assessed relocated people who came back after the disaster but didn't assess the relocated ones who didn’t come back after the disaster.

2)We assed people cross sectional and found some risk factors for being PTSD, so longitudinal studies are required for assessment of alleged predictive factors.

3) We took and analyzed self reported information. Self reported information is not excellent for reliability and validity. In that time, there is no enough objective data set resources, which is general problem in disaster zones in many studies.

In summary, this study reported prevalence and risk factors of PTSD among adults nine months after experiencing the 2011 Van earthquake. The results showed that PTSD was approximately three fold higher compared to the regular statistical rates. We observed specific pattern of demographic, clinical and event related features about earthquake in addition to some different regional differences. Especially, previous trauma related factors; severe trauma related effect, gender, and having depression may be important in that disaster area. Specific care and mental health intervention should be provided according to these factors.

Correspondence address: Assoc. Prof. Mehmet Hamid Boztas, Izzet Baysal University, Department of Psychiatry, Bolu, Turkey boztashamid@hotmail.com 


\section{REFERENCES}

1. Erdik M, Kamer Y, Demircioğlu M, Şeşetyan K. 23 October 2011 Van (Turkey) earthquake. Natural Hazards. 2012;64:65165.

2. Turkish Medical Association.Van Earthquake 2.nd Month Evaluation Report. http://www.ttb.org.tr/kutuphane/2ayrpr.pdf/turkish. Access Date February 25.02.2019

3. TESEV.Permanent solution to internal displacement? An assessment of the Van action plan for idp: Deniz Yükseker, Dilek Kurban / 26 May 2009 : http://tesev.org.tr/en/yayin/a-permanent-solution-to-internal-displacement-an-assessment-ofthe-van-action-plan-for-idps/ Access Date 27 April 2019

4. Xu J, Song X. A cross-sectional study among survivors of the 2008 Sichuan earthquake: prevalence and risk factors of posttraumatic stress disorder. Gen Hosp Psychiatry. 2011;33:386-92.

5. Xu J, Song X. Posttraumatic stress disorder among survivors of the Wenchuan earthquake 1 year after: prevalence and risk factors. Compr Psychiatry. 2011;52:431-7.

6. Livanou M, Başoğlu M, Salcioğlu E, Kalender D. Traumatic Stress Responses in Treatment-Seeking Earthquake Survivors in Turkey. The Journal of Nervous and Mental Disease. 2002;190 :816-23.

7. Salcioglu E, Basoglu M, Livanou M. Post-traumatic stress disorder and comorbid depression among survivors of the 1999 earthquake in Turkey. Disaster. 2007;31:115-29

8. Salcioglu E, Basoglu M, Livanou M. Long-term psychological outcome for non-treatment-seeking earthquake survivors in Turkey. J Nerv Ment Dis. 2003;191:154-60.

9. Tural U, Coskun B, Onder E, Corapcioglu A, Yildiz M, Kesepara C, Karakaya I, Aydin M, Erol A, torun F, Aybar G.. Psychological consequences of the 1999 earthquake in Turkey. J Trauma Stress. 2004;17:451-9.

10. Onder E, Tural U, Aker T, Kilic C, Erdogan S. Prevalence of psychiatric disorders three years after the 1999 earthquake in Turkey: Marmara Earthquake Survey (MES). Soc Psychiatry Psychiatr Epidemiol. 2006;41:868-74.

11. Kilic C, Ulusoy M. Psychological effects of the November 1999 earthquake in Turkey: an epidemiological study. Acta Psychiatr Scand. 2003;108:232-8.

12. Armenian HK, Morikawa M, Melkonian AK, Hovanesian AP, Haroutunian N, Saigh PA, Akiskal K, Akiskal HS. Loss as a determinant of PTSD in a cohort of adult survivors of the 1988 earthquake in Armenia: implications for policy. Acta Psychiatr Scand. 2000;102:58-64.

13. Cao H, McFarlane AC, Klimidis S. Prevalence of psychiatric disorder following the 1988 Yun Nan (China) earthquake--the first 5-month period. Soc Psychiatry Psychiatr Epidemiol. 2003;38:204-12.

14. Goenjian AK, Walling D, Steinberg AM, Roussos A, Goenjian HA, Pynoos RS. Depression and PTSD symptoms among bereaved adolescents 6(1/2) years after the 1988 Spitak earthquake. J Affect Disord. 2009;112:81-4.

15. Kun P, Tong X, Liu Y, Pei X, Luo H. What are the determinants of post-traumatic stress disorder: age, gender, ethnicity or other? Evidence from 2008 Wenchuan earthquake. Public Health. 2013;127:644-52.

16. Thienkrua W, Cardozo BL, Chakkraband ML, Guadamuz TE, Pengjuntr W, Tantipiwatanaskul P, Sakornsatian S, Ekassawin S, Panyayong B, Varangrat A, Tappero JW, Schreiber M, van Griensven F. Symptoms of posttraumatic stress disorder and depression among children in tsunami-affected areas in southern Thailand. JAMA. 2006;296:549-59.

17. Onder E, Tural U, Aker T, Kilic C, Erdogan S. Prevalence of psychiatric disorders three years after the 1999 earthquake in Turkey: Marmara Earthquake Survey (MES). Soc Psychiatry Psychiatr Epidemiol. 2006;41:868-74.

18. Salcioglu E, Basoglu M, Livanou M. Post-traumatic stress disorder and comorbid depression among survivors of the 1999 earthquake in Turkey. Disaster. 2007.

19. Fan F, Zhang Y, Yang Y, Mo L, Liu X. Symptoms of posttraumatic stress disorder, depression, and anxiety among adolescents following the 2008 Wenchuan earthquake in China. J Trauma Stress. 2011;24:44-53.

20. Sezgin U, Punamaki RL. Earthquake trauma and causal explanation associating with PTSD and other psychiatric disorders among South East Anatolian women. J Affect Disord. 2012;141:432-40.

21. Lock S, Rubin GJ, Murray V, Rogers MB, Amlot R, Williams R. Secondary stressors and extreme events and disasters: a systematic review of primary research from 2010-2011. PLoS Curr. 2012;4.

22. Zhou X, Kang L, Sun X, Song H, Mao W, Huang X, Zhang Y, Li J. Risk factors of mental illness among adult survivors after the Wenchuan earthquake. Soc Psychiatry Psychiatr Epidemiol. 2013;48:907-15.

23. Kienzler H, Pedersen D. Strange but common bedfellows: the relationship between humanitarians and the military in developing psychosocial interventions for civilian populations affected by armed conflict. Transcult Psychiatry. 2012;49:492518.

24. Cerda M, Paczkowski M, Galea S, Nemethy K, Pean C, Desvarieux M. Psychopathology in the aftermath of the Haiti earthquake: a population-based study of posttraumatic stress disorder and major depression. Depress Anxiety. 2013;30:41324.

25. Kilic C, Kilic EZ, Aydin IO. Effect of relocation and parental psychopathology on earthquake survivor-children's mental health. J Nerv Ment Dis. 2011;199:335-41.

26. Kadak MT, Nasiroglu S, Boysan M, Aydin A. Risk factors predicting posttraumatic stress reactions in adolescents after 2011 Van earthquake. Compr Psychiatry. 2013;54:982-90.

27. Ozdemir O, Boysan M, Guzel Ozdemir P, Yilmaz E. Relationships between posttraumatic stress disorder (PTSD), dissociation, quality of life, hopelessness, and suicidal ideation among earthquake survivors. Psychiatry Res. 2015;228:598-605.

28. Noorbala AA, Bagheri Yazdi SA, Yasamy MT, Mohammad K. Mental health survey of the adult population in Iran. Br J Psychiatry. 2004;184:70-3. 
29. Salcioglu E, Ozden S, Ari F. The Role of Relocation Patterns and Psychosocial Stressors in Posttraumatic Stress Disorder and Depression Among Earthquake Survivors. J Nerv Ment Dis. 2018;206:19-26.

30. Chan CL, Wang CW, Ho AH, Qu ZY, Wang XY, Ran MS, Mao WJ, Lu BQ, Zhang BQ, Zhang XL. Symptoms of posttraumatic stress disorder and depression among bereaved and nonbereaved survivors following the 2008 Sichuan earthquake. J Anxiety Disord. 2012;26:673-9.

31. Kılıç C. Turkey Mental Health Profile Report. In: Erol N, Kılı̧̧ C, Ulusoy M, Keçeci M, Şimşek Z, editors. Ankara: Ministry of Health of Turkey; 1998.pp,23

32. Maeng LY and Milad MR.Sex Differences in Anxiety Disorders: Interactions between Fear, Stress, and Gonadal Hormones. Horm Behav. 2015 November ; 76: 106-17.

33. Priebe S, Grappasonni I, Mari M, Dewey M, Petrelli F, Costa A. Posttraumatic stress disorder six months after an earthquake. Soc Psychiatry Psychiatr Epidemiol. 2008;44:393-7.

34. Norris FH, Friedman MJ, Watson PJ. 60,000 disaster victims speak: Part II. Summary and implications of the disaster mental health research. Psychiatry. 2002;65:240-60.

35. Basoglu M, Salcioglu E, Livanou M. Traumatic stress responses in earthquake survivors in Turkey. J Trauma Stress. 2002;15:269-76.

36. Shultz JM, Marcelin LH, Madanes SB, Espinel Z, Neria Y. The "Trauma Signature:" understanding the psychological consequences of the 2010 Haiti earthquake. Prehosp Disaster Med. 2011;26:353-66.

37. Livanou M, Basoglu M, Salcioglu E, Kalendar D. Traumatic stress responses in treatment-seeking earthquake survivors in Turkey. J Nerv Ment Dis. 2002;190:816-23.

38. Johannesson KB, Lundin T, Hultman CM, Lindam A, Dyster-Aas J, Arnberg F, Michel PO. The effect of traumatic bereavement on tsunami-exposed survivors. J Trauma Stress. 2009;22:497-504.

39. Kilic C, Ulusoy M. Psychological effects of the November 1999 earthquake in Turkey: an epidemiological study. Acta Psychiatr Scand. 2003;108:232-8.
40. Egan M, Tannahill C, Petticrew M, Thomas S. Psychosocial risk factors in home and community settings and their associations with population health and health inequalities: a systematic meta-review. BMC Public Health. 2008;8:239.

41. Roy MJ, Donaldson C, Baker R, Kerr S. The potential of social enterprise to enhance health and well-being: a model and systematic review. Soc Sci Med. 2014;123:182-93. Epub 2014/07/20.

42. Munir K, Ergene T, Tunaligil V, Erol N. A window of opportunity for the transformation of national mental health policy in Turkey following two major earthquakes. Harv Rev Psychiatry. 2004;12:238-51. 